\title{
WILDFIRE POLICY IN MEDITERRANEAN FRANCE: HOW FAR IS IT EFFICIENT AND SUSTAINABLE?
}

\author{
Thomas CURT ${ }^{1 *}$, Thibaut FREJAVILLE ${ }^{1,2}$ \\ ${ }^{1}$ IRSTEA RECOVER, Écosystèmes Méditerranéens et risques, Aix-en-Provence, France \\ 2 BIOGECO (UMR 1202), INRA, Université de Bordeaux, Pessac, France
}

*Corresponding author: thomas.curt@irstea.fr

\begin{abstract}
A new fire policy reinforcing aggressive fire suppression was established in Mediterranean France in response to the devastating wildfires of 1990's, but to which extent this has changed fire activity yet remains poorly understood. For this purpose we compared the number and location of ignitions and of burned areas between two 20-year periods (1975-1994 vs 1995-2014), in parallel to the changes in fuel covering, human activity promoting ignitions, and fire weather. The number of fires decreased almost continuously since 1975, but sharply after 1994, suggesting an effect of better fire prevention due to the new policy. But the major change in fire activity is a considerable reduction in fire size and burned areas after 1994, especially during summer and in the most fire-prone places, in response to massive efforts put into fire suppression. These reductions have occurred while the covering by fuel biomass, the human pressure on ignition and the fire weather index increased, thus making the study area more hazardous. Our results suggest that a strategy of aggressive fire suppression has great potential for counterbalancing the effects of climate changes and human activities and for controlling fire activity in the short term. However, we discuss whether such suppression-oriented approach is sustainable in the context of global changes, which cast new fire challenges as demonstrated by the devastative fires of 2003 and 2016. We advocate for a more comprehensive fire policy to come.
\end{abstract}

KEY-WORDS: fire policy; sustainable risk management; fire prevention; fire suppression; global changes, fire paradox 


\section{INTRODUCTION}

The pyrogeographic theory states that fire regime in a region depends upon three basic features: the availability of vegetation fuels $(1,2)$, the climate, and ignitions $(3,4)$. However, additional and often disregarded factors operating at local to regional scales such as fire policy may cause abrupt changes in fire activity (모). Indeed, policy can prevent ignition by humans, reduce the burned areas through suppression, modify fire behavior through fuel management (므) and thus mitigate the long-term risk of wildfires for humans and ecosystems. An efficient fire policy may thus act as a switching factor of fire activity in a similar magnitude to climate change (7). As a consequence, adapting fire policies to global changes (i.e. climatic and socio-economic changes) can thus become crucial for controlling fire activity in the long-term and reduce fire impacts on assets ( $\underline{8})$. Indeed, Euro-Mediterranean regions are characterized by increasing density of humans, infrastructures and wildland-urban interfaces, which increase the potential for ignition ( $\underline{9})$ and make suppression more complex (10). Together with the increased frequency of exceptional weather conditions, these issues promote fire activity, and notably large and devastating fires (11).

Following the devastating wildfires of the period 1973 to 1990, France established a new fire policy in about 1994. This policy aims at better preventing but above all at suppressing wildland fires in its Mediterranean fire-prone areas (12). Indeed, the French authorities feared that fire activity could increase due to the intermingling of urbanized areas and wildland, and the increase of tourism and infrastructures that may generate more ignitions. One-third of the budget has been allocated to prevention and two-thirds to suppression (13). Fire prevention has been reinforced through public information and limiting frequentation into forests during the peak fire season. Fuel reduction has remained local, mostly beside roads or at rural-urban interfaces where most ignitions occur. However, the cornerstone of the tactic was to ensure a systematic, rapid, hard-hitting initial attack on all ignitions, regardless the fuel type and the weather conditions. The objective was to avoid any fire developing to a size and a level of intensity which would make it difficult and more expensive to suppress (14), as it has been found that fire size and intensity grow exponentially with time during the buildup phase (ㅁ). In practice, firemen tend to extinguish fires before they reach one ha in size and in less than ten minutes in order to follow a heuristic (13).

Strong debates developed worldwide on the impact and the effectiveness of fire policies $(\underline{8}, \underline{15-17})$. Suppression-based policies have proved effective to reduce burned areas in boreal regions $(\underline{18-20})$. Likewise, increasing efforts of prevention and suppression in southern Europe may explain for a part the decrease of burned area since the mid-eighties in most countries, with the exception of Portugal $(21,22)$. However, many of these countries (Portugal, Spain, Greece) have also suffered devastating megafires (23). In California, some argue that suppression policy has allowed an unnatural accumulation of fuels (the 'fire paradox' effect sensu (24)) and thus increased fire hazard and massive fires (25) while others stated that fire suppression activities are not the cause of these fire events but rather exceptional weather conditions (26-28). In southern Europe, some authors argue that suppression may have caused more large fires and an increase in fire intensity $(\underline{29}, 30)$ while others indicate that fire reduction is a complex response to fire suppression strategies but also to past fires and weather $(\underline{31})$ and land cover changes $(\underline{32,33})$. A recent study in the western part of Mediterranean France has shown that fire policy has altered the way weather conditions drive fire activity, and has produced a shift from a drought-driven system to a system driven by concomitant fuel dryness and strong winds (푸).

In order to test the extent to which fire regime has changed due to the new fire policy, it is important to analyze how fire weather, fuel covering and ignitions have also changed during the same period. Disentangling the part played by these different fire drivers is crucial for determining whether fire 
regime can be stabilized at the present level. This is especially important in the context of global change because ignitions (predominantly human) may increase with population growth and the development of road networks and wildland-urban interfaces (35), fuel biomass and connectedness may increase due to the rural exodus syndrome $(\underline{36})$, forest planting or spontaneous reforestation after land abandonment and the positive fuel-fire feedback in shrublands ( $\underline{37})$. In addition, fire weather may be more conducive to fires, and the fire season becomes longer (23). However, no study has yet investigated the effect that this new fire policy has had on the extent, location, and timing of fire activity in southern France, in regards to fuel, weather, and ignitions. To this end, we compared the size distribution, location and seasonality of fires for two 20-year periods: 1975-1994 and 1995-2014. We aimed to determine the role of the new fire policy on fire activity, if it is sustainable in the context of global changes, and how it can be improved.

\section{MATERIALS AND METHODS \\ 2.1. Study area}

Our case-study region is the southeastern part of France, which covers $80500 \mathrm{~km}^{2}$ (Fig. 1). This fireprone area encompasses wide bioclimatic, environmental and anthropogenic gradients. The study area includes Mediterranean lowlands propitious to fire activity (ㄱ) and heat-waves (마), mid-elevation hinterlands and foothills with supra-Mediterranean climate, and mountain areas (western Alps, Corsica, and Pyrénées) (Fig. 1). Elevation ranges from 0 to 2000 meters a.s.l. (Fig. 1).

This area also exhibits a range of land covers and land uses, from cultivated lands and orchards with very low flammability to highly flammable forests and shrublands. Mediterranean forests are dominated by Pinus halepensis Mill. and Quercus species, while mountain forests are dominated by Pinus sylvestris L., Pinus nigra Arn., Fagus sylvatica L. and Abies alba Mill. Flammable shrublands (so-called garrigues and maquis) are common in the southernmost part of the study area. They are dominated by Quercus coccifera L., Ulex parviflorus Pourr., Cistus spp., and Erica arborea L. Human presence and activity both vary from the Mediterranean coast with its high concentration of people, infrastructure and resorts to rural hinterland with very low human density.

\subsection{Fire data}

We used the fire data from the French Prométhée database, which includes all fires that affected forests or wildland since 1973 in the 15 departments of southeastern France (39). Prométhée specifically provides information on the date and size of fires, and their location on a $2 * 2 \mathrm{~km}$ grid comprising 20,142 pixels. Like many fire databases in Europe (see (40)), Prométhée contains a number of data errors (e.g. false location) and incomplete data. In a previous work, we have made an extensive effort to correct the data in order to prevent spatial and temporal biases (7). As in many fire databases worldwide (21), the minimum area recorded varied with time: it was of 0.1 ha before 1990 then 0.0001 ha. We tested this effect, but it was negligible on the cumulated burned because the smallest fires $(<1$ ha) account for a very small proportion of the total. We have thus separated fires into five classes: $<1$ ha, 1-10 ha, 10.1-50 ha, 50.1-100 ha, and $>100$ ha. These classes corresponded approximately to the percentiles 70,95,97, 98 and 99 of the distribution of fire size in our database, and to thresholds commonly used in Euro-Mediterranean countries ( $\underline{23})$.

\subsection{History of fire policies}

In France, fire activity is known with accuracy since 1973. This corresponds to the establishment of the first fire policy of the modern era including notably the setting of the Prométhée database and the computation of the fire weather index for prediction of daily fire danger (see Fig. 9). Many fires raged from 1976 to the 1990s, including the largest fires ever recorded in southeastern France (11,580 ha in 
1990 in Provence). A new fire policy and strategy called 'Vulcain' was progressively set up from 1992 to 1994 in response to these devastative fires (12). This strategy promoted the reinforcement of prevention to suppression, with particular emphasis on massive suppression of all ignitions (41). Vulcain still remains an important milestone in the history of modern fire policies in France, even if gradual adjustments have been made to account for the 2003 fires $(\underline{42})$ or for the potential impacts of climate changes $(13)$. We consider 1994 to be the date from which the new fire policy was fully established throughout the study area. We thus compared two 20-year periods: 1975-1994 and 19952014. We discarded the years 1973 and 1974 for which fire data was incomplete. In total, the data included 103,456 fires and a cumulated area of 818,342 hectares.

\subsection{Fire size distribution}

We compared the distribution of the number of fires and the burned areas among the two study periods using the qqplots R function ( $\underline{43})$. This indicates how much the two distribution differs, and computing the percentiles of burned areas.

\subsection{Temporal and spatial distribution of fires}

We tested whether the number of fires and the total burned area have changed after 1994 for each of the five classes of fire size ( $<1$ ha, 1-10 ha, 10.1-50 ha, 50.1-100 ha, and $>100$ ha) in comparison to before 1994. Changes (\%) were computed as 1995-2014 minus 1975-1994, relative to 1975-1994. For each size class, $p$-values and standard deviation were computed by bootstrapping (1000 runs with $70 \%$ randomly sampled data points with replacement). Results were considered significant if $p<0.001$. We also tested whether the seasonal distribution of the mean annual fire density and the mean annual area burned differed among the five fire size classes and between the two periods (1975-1994 versus 19952014). For this purpose we computed the seasonal changes (\%) in the number of fires and the total burned area between 1995-2014 and 1975-1994, relative to 1975-1994. For each season, p-values and standard deviation were computed by bootstrapping 1000 runs with $70 \%$ randomly sampled data points with replacement. Results were considered significant if $\mathrm{p}<0.001$.

Both the climate and the fire activity varied across our study area, thus defining pyroclimatic regions (7). Two regions were especially fire-prone: the maritime mountains of Corsica and Maritime Alps, and the lowlands of Provence and Languedoc-Roussillon-Cévennes. The less fire-prone areas correspond to hinterland mountains of the Alps, Pyrénées and Massif Central (Fig. 1). It is thus crucial to determine if the establishment of the new policy has impacted all regions or not, because this can have implications for adapting specific measures of prevention and suppression. For this purpose we computed fire density and burned areas kernels maps for the two periods (1975-1994 and 1995-2014), and we used analyses of variance and HSD post-hoc tests to compare the number of fires and the burned area before and after 1994 in each of the three pyroclimatic regions.

In order to determine the location of the hotspots of number of fires and burned areas, we used a kernel density estimation under using the R package kedd (43), which is a non-parametric method of estimating the probability density function of a continuous variable. This method is acknowledged as efficient among the spatial autocorrelation statistics that exist (44-46).

\subsection{Computation of fire drivers}

We investigated if the human and environmental drivers of fire (i.e. fire weather, ignitions, and fuels; (47) changed after 1994 and could have thus impacted fire activity along with the new policy. These data were calculated on the same $2 * 2 \mathrm{~km}$ grid than the fire data. 
The fire weather index (FWI) is a unitless index originally designed to forecast fire risk in Canada on the basis of past and current weather condition $(\underline{48})$. We calculated FWI daily by combining five subindices which use daily values of air temperature, air relative humidity, surface wind speed, and rainfall in the past 24 hours for the whole study area (see () for details). The daily meteorological data were taken from the SAFRAN reanalysis system implemented by MeteoFrance, at a spatial resolution of $8 * 8 \mathrm{~km}(\underline{49})$. They were interpolated to $1 \times 1 \mathrm{~km}$ resolution with the help of regional statistical modelling using lapse rates (see (50), using regionalized linear regressions for each homogeneous climatic zone (called 'symposium', (49)). FWI provides a numeric method for rating fire danger and potential fire intensity through the probability and ease of ignition and propagation of a fire on the forest floor, taking into account the weather conditions. It is acknowledged as a good indicator of meteorological fire hazard worldwide, notably in Mediterranean areas (51).

We also calculated a 'human pressure index' (HPI) which estimates the potential amount of ignitions caused by humans, which contribute for $90 \%$ of all ignitions in the study area (2). HPI sums the logtransformed density of population, houses and tourists based on data at the municipality level (source: Insee). For each data we computed values 1975-1994 and 1995-2014 at the 2*2 km grid. Natural ignitions caused by lightning strikes were not considered because they are a minority.

In order to estimate the availability of flammable wildland fuels in our study area, we computed the coverage by flammable fuels within each $2 * 2 \mathrm{~km}$ pixel. We used CORINE Land Cover (CLC) data in 1990 for the pre-1994 period, and in 2006 and 2012 for the post-1994 period. Flammable fuels comprised all forests (CLC 3.1), shrublands-grasslands-heathlands and herbaceous vegetation (CLC 3.2) and pastures (CLC 2.3) which are the most likely to burn and to propagate fire (37). We compared the total area of flammable fuels before and after 1994 using an analysis of variance with a KruskalWallis test.

As we hypothesized that fire suppression may have a strong impact on fire activity, we also calculated an index of 'fire suppression effort' which combines the quantity of fire crews in each fire brigade, the ground fire suppression means such as trucks and fire patrols, and the financial investments in suppression in each of the 15 departments of the study area. We did not consider the aircraft detection and the water bomber aircrafts, which can intervene throughout the study area and thus can be considered as spatially uniform. These data are incomplete and unreliable for the pre-1994 period, but we had data of good quality for 2012 at the scale of fire brigades and municipalities (source: DGSGC 2012). For each $2 * 2 \mathrm{~km}$ pixel, this index was compared to the temporal trends (tau statistic of modified Mann-Kendall trend tests; R package 'fume') in fire number and burned area, which were computed by (7) over 1973-2009. This indicates to what extent the spatial variation in fire suppression capacity may affect fire activity based on the current system established in 1994.

\section{RESULTS}

Overall, our results reveal that several important features of fire activity decreased throughout southeastern France after the establishment of the new policy in 1994, while at the same time the environmental and human drivers promoting fire activity (i.e. fire weather hazard, human pressure on ignitions and the fuel coverage) increased.

\subsection{Changes in fire activity $1975-1994$ versus $1995-2014$}

The total number of fires decreased of ca. $25 \%$ and the total area burned of ca. $60 \%$ after 1994 (Table 1), thus making the fire cycle jumping from 276 years to 684 years. Despite large annual fluctuations, 
the number of fires has decreased almost linearly since 1975 (Fig. 2), whereas the burned area changed more abruptly. Indeed, the mean annual area burned was more than 30,000 ha before 1994 with large interannual fluctuations: every 2-3 years the area burned peaked up to 50,000 ha (Fig. 2). After 1994, the mean annual burned area peaked dramatically at 12,650 ha, and interannual fluctuations were reduced except in 2003 (Fig. 2). If we discard the exceptional year 2003 from the second period, the mean annual burned area is only ca. 8000 ha, that is to say $0.001 \%$ of the study area. In 2013 and 2014, France has recorded the lowest number of fires and the lowest annual burned since 1975.

Clear changes also occurred after 1994 for all fire size classes: the number of fires (Fig. 3A) and the total burned area (Fig. 3B) followed the same tendency than the annual amounts for all size classes, with a clear decrease since 1994 . The only exception is the number of very small fires $(<1 \mathrm{ha})$ which decreased weakly. Changes were also visible in the allocation into fire size classes. The annual number of very small fires $(<1 \mathrm{ha})$ decreased weekly but all fires larger than 1 ha were significantly less abundant after 1994 (Table 2; Fig. S1A). The total burned areas greatly decreased for all fire size classes including small (1 ha) fires (Table 2; Fig. S1B). The fire size distribution curves show that the number of fires and the area burned were clearly lower after 1994 (Fig. 4). The gap between the curves increases with the fire size classes, especially for the burned area (Fig. S2A) than for the number of fires (Fig. S2B). The comparison of percentiles indicates that $95 \%$ of wildfires were suppressed before reaching 8 ha in size after 1994 instead of 15 ha before 1994.

The seasonal distribution of fire activity was also modified. The number of fires was dramatically reduced in summer (July to the end of September) but less during the 'winter' season from October to June (Table 3; Fig. 5A). The burned area decreased sharply during summer and moderately from autumn to spring (Table 3; Fig. 5B). Overall, the daily peaks of burned area (i.e. maximal area burned on a certain day) were clearly reduced after 1994 (Fig. 5B).

The kernel density maps show hotspots of fire activity in Corsica, along the Mediterranean coast and in the Cévennes-Ardèche hinterland (Fig. 6). The comparison of maps before and after 1994 indicated that the hotspots remained rather similar but that their size and their values decreased. The fire density decreased throughout the study area after 1994 (Fig. 6A and 6B) even if local variations exist (Fig. S3). The burned area sharply decreased, especially in the most fire-prone areas of Corsica and the Maritime Alps, and in the coastal lowlands (Fig. 6C and 6D; Fig. S3). The tests of changes at the scale of pyroclimatic regions indicated that the number of fires and the burned area decreased is statistically significant in all regions (Table 4) although there was local variability at the scale of the $2 * 2 \mathrm{~km}$ pixels.

\subsection{Changes in environmental and human drivers of fire}

The analysis of the pre- and post-1994 periods indicates that the main environmental drivers of fires (fuels, weather and anthropogenic activities promoting ignitions) increased. The fire weather hazard increased almost linearly since 1975, and this tendency continued after 1994 (Fig. 2). Indeed, the FWI index which estimates the wildfire potential was $22 \pm 2.9$ (mean \pm SD) before 1994 then $25 \pm 3.9$ after 1994 ( $\mathrm{F}=7.86 ; \mathrm{P}=0.0079$ ) (Fig. 7 right panel). Likewise, the human pressure index (HPI) which estimates the amount of ignitions linked to human activities statistically significantly increased after 1994 ( $\mathrm{F}=3.92 ; \mathrm{P}=0.047)$. The fuel coverage in the whole study has increased of about $3 \%$ after 1994. The shrublands, the forested shrublands and the forests are the main fuel types that have increased after 1994 (Fig. 8). These fuels have expanded to the detriment of agricultural lands, pastures and sparse vegetation. A large part of pastures (and a small part of agricultural lands) were progressively transformed into shrublands and sparse vegetation. A part of sparse vegetation also transferred into shrublands. Transfers among the major fuel types (shrublands and forests) were also important, with many shrublands evolving towards wooded shrublands or forests, and wooded shrublands evolving towards forests. This suggests that the fuel biomass has also increased, although 
specific data of biomass are missing. An interesting finding is that the number of fires and the burned area clearly decreased the most where fire suppression effort is high and strong (very high), especially during the summer season (Fig. 9).

\section{DISCUSSION}

\subsection{The efficiency and impacts of the new fire policy since 1994}

The new fire policy adopted in 1994 marked an important milestone $(12,41)$. The effectiveness of fire surveillance, fast detection and massive suppression has undoubtedly reduced fire activity, especially in the historical fire hotspots. It can thus be seen as effective because fire activity has considerably decreased during the two following decades while many factors promoting fires have increased during the same time. A series of variables clearly indicate a decline in fire activity. The number of wildfires was halved in comparison to the pre-1994 situation, likely resulting from the reinforced prevention and surveillance of forests, and from higher communication on daily fire danger ( $\underline{41})$. Fire frequency tended to diminish slowly since 1975 from the establishment of the first modern policy (Fig. 10) but the decrease was sharply accentuated after 1994. However, the major successes of the new fire policy were registered on burned areas, which were reduced to an unprecedented level. The total burned area annually peaked to one fifth of the initial (1970's) due to the strategy of massive attack with all the means available (10), coupled with the pre-positioning of fire crews and the reinforced surveillance in wildland. This strategy aimed at preventing fire propagation and reducing the size of fire at the moment of attack. This reduction of burned area affected all fire size classes. The total area burned by very large fires thus became low except in 2003, and $95 \%$ of wildfires were suppressed before reaching 8 ha in size before 1994 instead of 15 ha before 1994 (Fig. 4). The burned area was reduced throughout the study area but mostly in densely-populated and fire-prone areas with many values at risk, and especially during the hazardous summer season. All these results reflect the fact that the policy was mostly oriented toward the suppression of hotspots and focused on the major human stakes. This argument is corroborated by fact that the fire suppression effort strongly controlled the fire density and the burned area, notably during summer (Fig. 9).

Meanwhile, the south-eastern France became a more fire-hazardous area on average. Indeed, the potential for human-caused ignitions increased in parallel to the expansion of population and tourism (53), infrastructures (52) and wildland-urban interfaces (54) which generate most of fire ignitions. Likewise, the fuel coverage increased thanks to shrub encroachment into agricultural or pastoral areas and to the spontaneous afforestation with pines and oaks into many shrublands. These land cover changes due to the 'rural abandonment syndrome' are widespread in France as in the southern Europe, leading to more fire-hazardous landscapes ( $\underline{36})$. The fire weather hazard (FWI value) also increased significantly in southeastern France due to climate changes and global warming (7), and the occurrence of synoptic conditions propitious to large fires driven by wind (ㅌ5) or by heat $(\underline{38})$ increased.

Fire activity has thus become low in southeastern France (9.7\% of the total number of fires and 5.5\% of the burned areas in Europe; see (56)) in comparison to Spain, Greece and Portugal, although their situation has improved recently $(\underline{22}, \underline{57})$. These successes are only possible because France benefits from a high ratio of fire suppression means in relation to the annual burned area (ㅇ) $)$ Investment in equipment and preparedness has been considerable since 1994, including air trackers, water bomber aircrafts, and fire suppression crews. The suppression capacity has captured two-thirds of national funding for wildfires while only one third goes to prevention $(\underline{13}, \underline{58})$. In addition, the density of road 
networks generally allows rapid access to most fires. However, this costly system could be called into question in the future due to budget cuts $(\underline{13}, \underline{42}, \underline{59})$.

\subsection{What could limit the sustainability of the new fire policy?}

This study confirms that an aggressive suppression-based fire policy can counterbalance in the short run environmental conditions and human activity that become more hazardous $(\underline{5}, \underline{34})$. In 'normal' weather years the current system of fire suppression is well organized, directed, equipped, and remarkably efficient. However, increasing evidences suggest that these policies are challenged in the long-term by several facts. Indeed, large and devastative fires occurred in 2003 and in 2016, burning thousands of hectares and destroying many houses of infrastructures. These dramatic events are indicative of structural factors becoming more conducive to fires in the long term, and of the difficulty to manage prevention and suppression under exceptional circumstances. However, the current policy does not fully address the future fire challenges: it does not account for the increase of structural factors promoting fire risk, for climate changes, and it is unbalanced (Fig. 10).

Fire risk would increase due to several factors. Fuel coverage and biomass still grow due to encroachment and spontaneous afforestation ( $\underline{36})$, and low practice of fuel management, in particular around houses (13). This is exacerbated by the fire paradox: active suppression practiced since 1994 increased the fuel biomass and the likelihood of intense and large fires (24). Exurban sprawl into wildland promotes ignitions and increases the vulnerability of houses (54), and makes suppression more challenging (10). More generally, the expansion of infrastructures and tourism promotes ignitions and hazardous areas where humans and assets are exposed to high fire hazard. In the same time, there may be concerns more specific to southern France: as fire use for agricultural purpose is banned from many areas, the culture of firewise practices decreased among population. Likewise, the reduction of fire activity and fatalities gave credence increases in the media that the current system cannot be overwhelmed; this may demobilize the public decision-makers (모) and decrease the memory of fire the general public (see $(\underline{60})$ ). These structural changes are exacerbated by the ongoing climate changes. Higher temperatures increase fuel dryness (1ㅡ) and produce more necromass ( $\underline{62})$ thus promoting intense fires (즈). Exceptional meteorological events (heat droughts, heat waves) like 2003 and 2016 promote concomitant fires of high intensity (효) which are likely to overwhelm the suppression capacity of fire crews (며). This may foreshadow the near-normal fire activity in the longterm ( $\underline{13})$. The present suppression-oriented policy is unbalanced because it places too little emphasis on prevention ( $\underline{65}$ ), and on hinterland and rural areas where prevention and regulation could be effective to control future fires.

The unprecedented combination of increasing structural fire hazard, climate changes and unbalanced policy seems to be a syndrome common to many Euro-Mediterranean countries (ㅁ6 $)$ and would be the origin of a new generation of wildfires intense and difficult to suppress $(\underline{67}, \underline{68})$.

\subsection{Facing new challenges: towards sustainable fire policy and adaptive land management}

Since 1973 the French fire policy has recurrently tried to adapt to fire challenges after the fact (Fig. $\underline{10})$. Following the 2003 fires when the fire suppression framework collapsed (느), the firemen now adopt a 'fire analysis' (10) approach for better detecting and fighting large fires, based on the Catalonian approach (9). In 2010, the potential effects of climate change on fires were investigated by $(\underline{13})$, and in 2016, policy makers have questioned the sustainability of the current policy (무) facing possible budget costs while suppressing fires tends to be more dangerous and expensive (14). Such reflections about sustainable fire policies have recently gained momentum worldwide (see (14-16). A new perspective is to better cope and coexist with fire in a context of global changes based on the assumption that fire cannot be fully extirpated from our territories (see (15)). A consensus also emerged on the fact that sustainable fire policies are those which favor prevention, participation of 
people to the culture and memory of fire, and long-term management of fuels and areas at risk $(\underline{8}, \underline{69})$. This would limit unwanted ignitions, tolerate them where and when this is possible, while protecting the human assets from destructive fires and decreasing their vulnerability. This includes self-protection of people against fire at a local scale, because fire cannot be the exclusive issue of firemen. A comprehensive vision of this future is encapsulated into the 'fire-smart territory' approach (므) which promotes firewise communities and fire-smart landscapes (Fig. 10).

\section{CONCLUSION}

In this study we showed that the fire policy established after the devastating wildfires of 1990 has been very effective for reducing fire activity in southeastern France. The strong financial, technological and human investments made to implement this policy of aggressive suppression, pre-positioning and prevention have offset the effects of increasing human activities promoting ignitions, of increased fire weather hazard, and of the expansion of flammable fuels. France is thus often referred to as the good pupil in the matter in Europe because its fire suppression framework is effective under normal weather conditions. However, we strongly question the sustainability of this policy and its ability to mitigate fire risk in the long-term in a context of increasing fuels and fire weather hazard. The hazardous fires of 2003 and 2016 have recalled policy-makers to order and reminded that a suppression-driven policy can collapse when facing exceptional weather conditions and new generations of fires that challenge firemen. We advocate for a comprehensive and sustainable fire policy allowing coexistence with wildfires. It should include reinforced prevention, involve the participation public and private, and promote fire-smart landscapes and fire-resistant/resilient ecosystems.

\section{ACKNOWLEDGMENTS}

We greatly acknowledge the Prométhée fire database (www.promethee.com) for providing fire data. This study was funded by The FUME research project (Forest fire under climate, social and economic changes in Europe, the Mediterranean and other fire-affected areas of the World) funded by the European Community‘s Seventh Framework Program (2010-2013) under grant agreement $n^{\circ} 243888$.

Table 1. Characteristics of fire activity and environmental-human drivers (mean \pm SD) in southeastern France (1975-1994 versus 1995-2014)

\begin{tabular}{|c|c|c|c|c|c|}
\hline Characteristics of fire activity & 1975-1994 & 1995-2014 & Total & F ratio & P-value \\
\hline Total number of fires $(\mathrm{n})$ & 58813 & 44642 & 103455 & & \\
\hline $\begin{array}{l}\text { Mean annual fire density (n. } \mathrm{yr}^{-} \\
{ }^{1}, \text { mean } \pm \text { SE) }\end{array}$ & $2940 \pm 680$ & $2232 \pm 556$ & $2586 \pm 710$ & & \\
\hline $\begin{array}{l}\text { Annual fire density }\left(\mathrm{n} \cdot \mathrm{yr}^{-1} \cdot \mathrm{km}^{-2} \text {, }\right. \\
\text { mean) }\end{array}$ & 0.037 & 0.028 & 0.032 & 12.44 & 0.0011 \\
\hline Total burned area $\left(\mathrm{km}^{2}\right)$ & 5829 & 2355 & 8183 & & \\
\hline $\begin{array}{l}\text { Annual burned area (ha. } \mathrm{yr}^{-1} \cdot \mathrm{km}^{-} \\
{ }^{2}, \text { mean } \pm \text { SE) }\end{array}$ & $0.36 \pm 0.02$ & $0.15 \pm 0.02$ & $0.25 \pm 0.02$ & 13.91 & 0.0006 \\
\hline Fire cycle (yrs.) & 276 & 684 & 393 & & \\
\hline \multicolumn{6}{|l|}{ Environmental-Human Drivers } \\
\hline Fire Weather Index & $22 \pm 2.9$ & $24.9 \pm 3.6$ & $23.4 \pm 3.5$ & 7.86 & 0.0079 \\
\hline Human Pressure Index & $1665 \pm 154$ & $2115 \pm 167$ & $1890 \pm 180$ & 3.92 & 0.0047 \\
\hline Fuel Coverage & $6625 \pm 75$ & $6814 \pm 50$ & $6720 \pm 67$ & 6.50 & 0.0090 \\
\hline
\end{tabular}


Table 2. Changes (\%) in the number of fires and the total burned area by fire size classes between 1995-2014 and 1975-1994 (relative to 1975-1994). For each size class, p-values and SD were computed by bootstrapping (1000 runs with $70 \%$ randomly sampled data points with replacement. Mean values $( \pm \mathrm{SD})$ are reported, all are significant at $p<0.001$.

\begin{tabular}{|l|c|c|c|c|c|}
\hline & $<1$ ha & $1-10$ ha & $10-50$ ha & $50-100$ ha & $>100$ ha \\
\hline $\begin{array}{l}\text { Number of } \\
\text { fires }\end{array}$ & $\begin{array}{c}-16 \pm 0.4 \\
* * *\end{array}$ & $-48.8 \pm 0.5 * * *$ & $-52.1 \pm 1 * * *$ & $-49.1 \pm 2.7 * * *$ & $-59.2 \pm 1.9 * * *$ \\
\hline Burned area & $\begin{array}{c}-44 \pm 0.4 \\
* * *\end{array}$ & $-52.5 \pm 0.5 * * *$ & $-55.1 \pm 1.1 * * *$ & $-52 \pm 2.5 * * *$ & $-62.3 \pm 3.2 * * *$ \\
\hline
\end{tabular}

Table 3. Seasonal changes (\%) in the number of fires and the total burned area between 1995-2014 and 1975-1994 (relative to 1975-1994). Mean values ( \pm SD) are reported, all are significant at $p<$ 0.001 . For each season, $p$-values and SD were computed by bootstrapping (1000 runs with $70 \%$ randomly sampled data points with replacement)

\begin{tabular}{|l|c|c|c|c|}
\hline & Winter & Spring & Summer & Autumn \\
\hline Number of fires & $-20.5 \pm 0.8 * * *$ & $-12 \pm 0.9^{* * *}$ & $-32.7 \pm 0.4 * * *$ & $-28.2 \pm 0.9 * * *$ \\
\hline Burned area & $-50.9 \pm 2.8^{* * *}$ & $-58.2 \pm 2.9 * * *$ & $-60.4 \pm 3.2 * * *$ & $-62.3 \pm 4.6^{* * *}$ \\
\hline
\end{tabular}


Table 4. Comparison of the number of fires and the burned area (1975-1994 versus 1995-2014) for each of the three pyroclimatic regions (PC). Comparisons were made using an analysis of variance with a post hoc Bonferroni test. P-values lower that 0.05 are statistically significant

\begin{tabular}{|c|c|c|c|c|c|}
\hline Number of fires & $\mathbf{1 9 7 5 - 1 9 9 4}$ & $\mathbf{1 9 9 5 - 2 0 1 4}$ & Total & F ratio & P-value \\
\hline PC1 & 24226 & 18762 & 42988 & 7.35 & 0.0033 \\
\hline PC2 & 32355 & 22899 & 55254 & 10.21 & 0.0014 \\
\hline PC3 & 2981 & 2232 & 5213 & 3.83 & 0.0042 \\
\hline Total & 59562 & 43893 & 103455 & & \\
\hline & & & & & \\
\hline Burned area (km $\mathbf{2})$ & $\mathbf{1 9 7 5 - 1 9 9 4}$ & $\mathbf{1 9 9 5 - 2 0 1 4}$ & Total & F ratio & P-value \\
\hline PC1 & 2462 & 1025 & 3487 & 21.53 & $<0.0001$ \\
\hline PC2 & 3111 & 1159 & 4270 & 16.66 & $<0.0001$ \\
\hline PC3 & 255 & 171 & 426 & 12.62 & 0.0004 \\
\hline Total & 5829 & 2355 & 8183 & & \\
\hline
\end{tabular}




\section{Figure captions}

Figure 1. Location and elevation map of the study area. The upper right box displays the three main pyroclimates (modified from Fréjaville and Curt 2015)

Figure 2. Mean annual number of fires and total burned area in southeastern France (1975-2014). The dotted grey bar indicates the setting of the new fire policy

Figure 3. Number of fires (A) and total burned area (B) along the 1975-2014 period for different fire size classes. The vertical grey dotted line indicate the transition between the two periods 1975-1994 and 1995-2014

Figure 4. Fire size distribution (A) and burned area distribution (B) in southeastern France (19751994 versus 1995-2014). The vertical and horizontal scales are log-transformed

Figure 5. Comparison of the cumulated daily number of fires (A) and the mean daily burned area (B) in southeastern France (1975-1994 versus 1995-2014)

Figure 6. Kernel distribution of the number of the mean fire density (A: 1975-1994; B: 1995-2014) and of the mean burned area (C: 1975-1994; D: 1995-2014) in southeastern France

Figure 7. Changes in fire activity (left panel) and in the drivers of fire activity (right panel) for the period 1975-1994 versus the period 1995-2014. The difference between the two periods has been computed using $\mathrm{F}$ tests on 20,142 pixels. NS: non-significant at a level of $0.05 ; * \mathrm{P}<0.05 ;{ }^{* *} \mathrm{P}<$ $0.01 ; * * * \mathrm{P}<0.0001$

Figure 8. Sketch of the main changes in fuel coverage before and after the new fire policy (1994) using the CORINE Land Cover (1990 and 2012). For the fuel types having increased the most in coverage between 1990 and 2012, the percentage of increase in indicated. Conversions from one fuel type to another are indicated in \%. These fuel types contributed for $95 \%$ of the increase in fuel biomass from 1990 to 2012. AGRIC: agricultural lands; SPARSE: sparse vegetation; PAST: pastures; SHRUBL: shrublands; FORSHRUB: woody shrublands; FOREST: forests of all types

Figure 9. Contrasting seasonal patterns (left, winter: December to February; right, summer: June to August) of temporal fire trends (top, fire density; bottom, burned area) with spatial variation in fire suppression effort (x-axis, increasing suppression from left to right). Temporal trends were computed by the tau' statistic of Mann-Kendall modified trend tests in each pixel from log-transformed fire variables over 1973-2009. For each class (quantiles 0-25, 25-50, 50-75, 75-100) of the fire suppression index, distribution of tau values was compared to a zero-centered random distribution using Student tests within a bootstrap re-sampling procedure. Significant positive or negative trends by class of fire suppression effort are indicated by asterisks $(* \mathrm{p}<0.05, * * \mathrm{p}<0.01, * * * \mathrm{p}<0.001)$

Figure 10. Temporal sketch of fire policy in Mediterranean France since 1975. The lower graph indicates the variations of annual burned area, and periods of high fire activity in red. The central text indicates the main fire policy options according to time. The upper arrow indicates the structural causes and drivers that likely increase fire hazard and fire risk along time 
Author-produced version of the article published in Risk Analysis, 2018, 38, 3, 524-533.

The original publication is available at https://onlinelibrary.wiley.com/doi/full/10.1111/risa.12855

DOI: 10.1111/risa.12855

Fig. 1

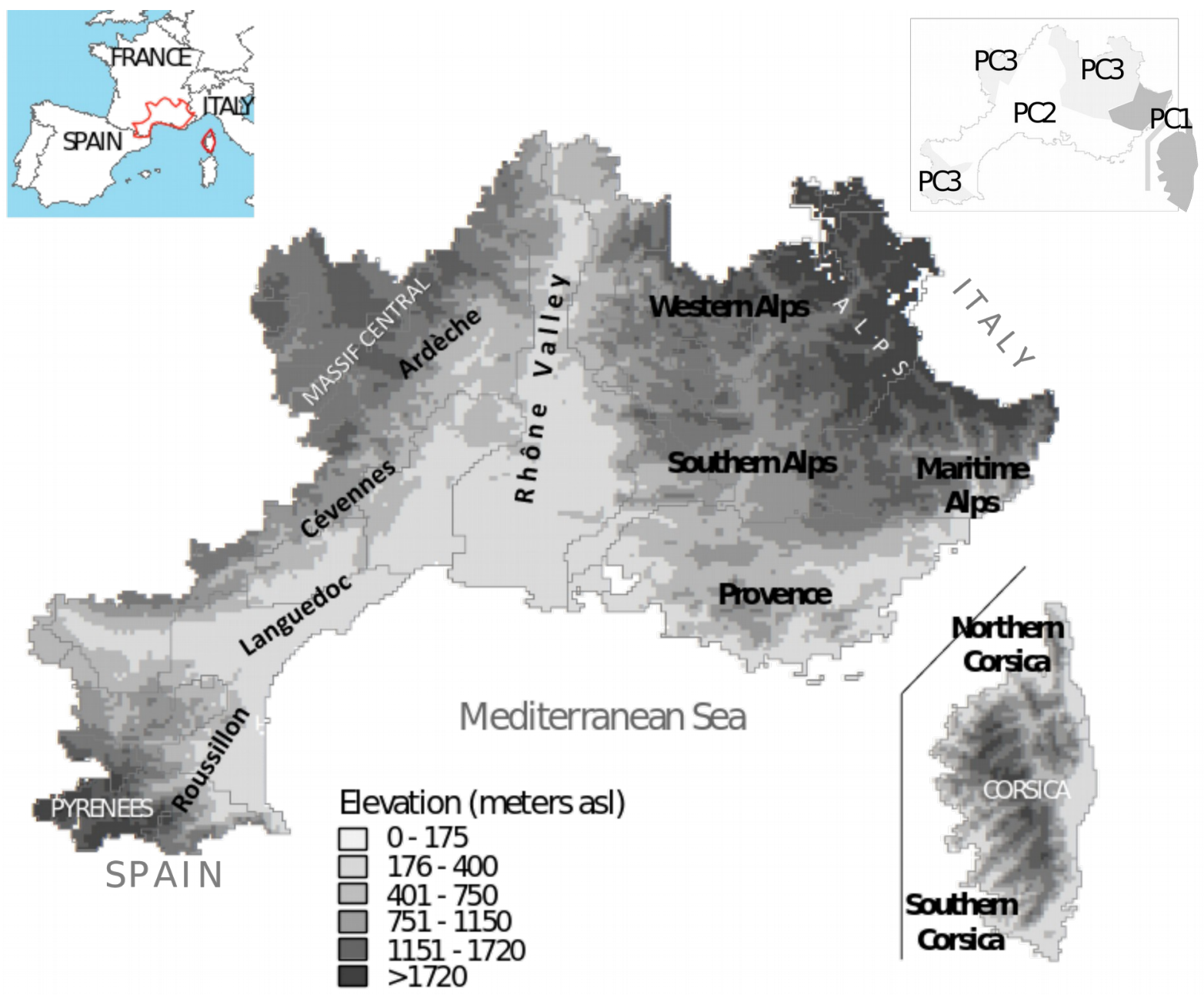


Author-produced version of the article published in Risk Analysis, 2018, 38, 3, 524-533.

The original publication is available at https://onlinelibrary.wiley.com/doi/full/10.1111/risa.12855

DOI: 10.1111/risa.12855

Fig. 2
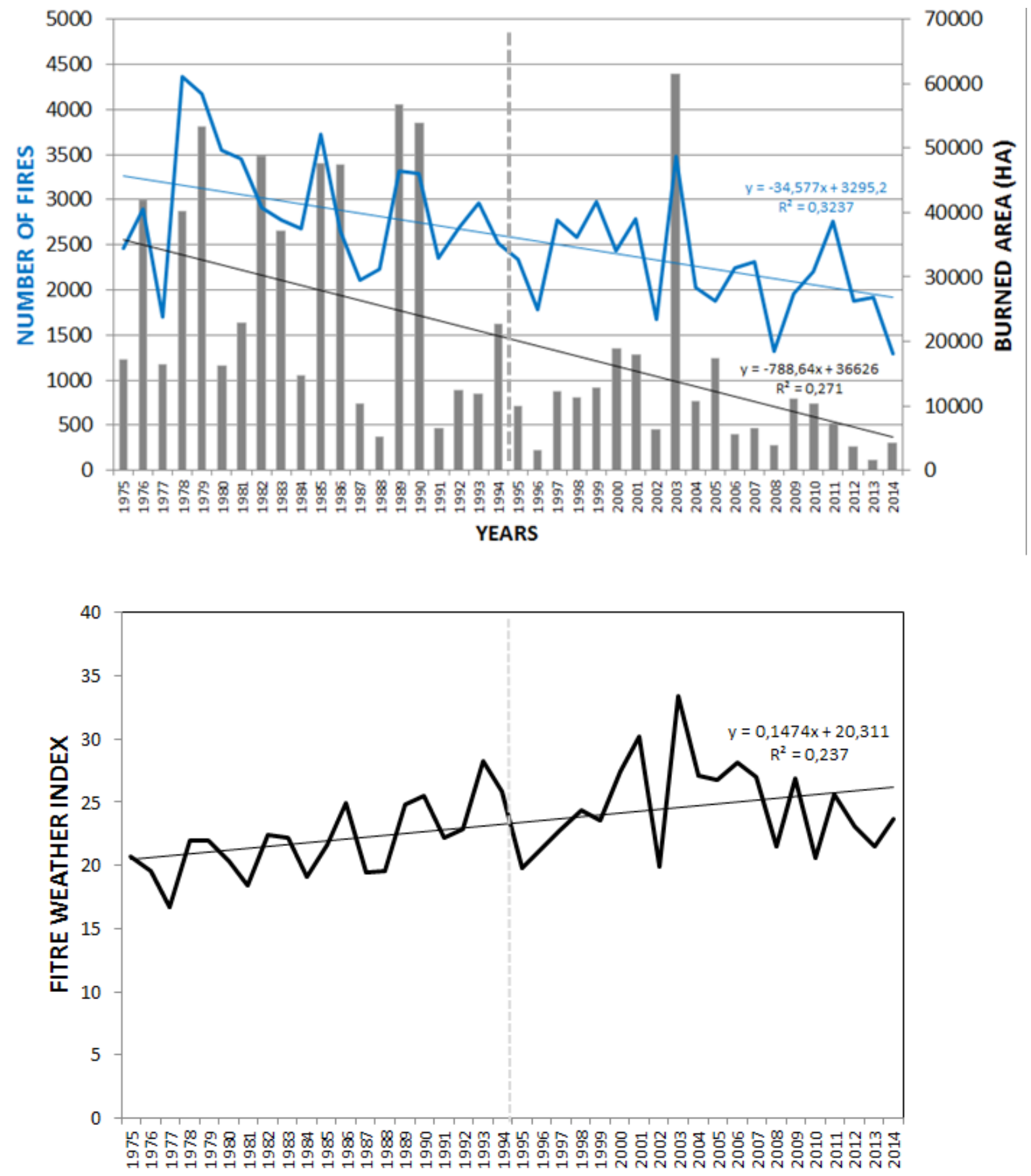

YEARS 
Author-produced version of the article published in Risk Analysis, 2018, 38, 3, 524-533.

The original publication is available at https://onlinelibrary.wiley.com/doi/full/10.1111/risa.12855

DOI: 10.1111/risa.12855

Fig. 3

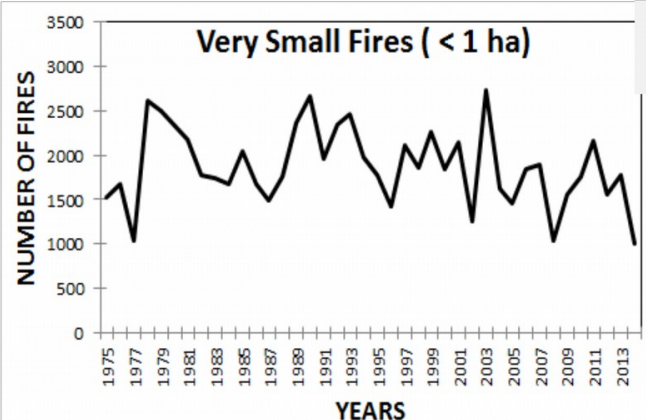

A B
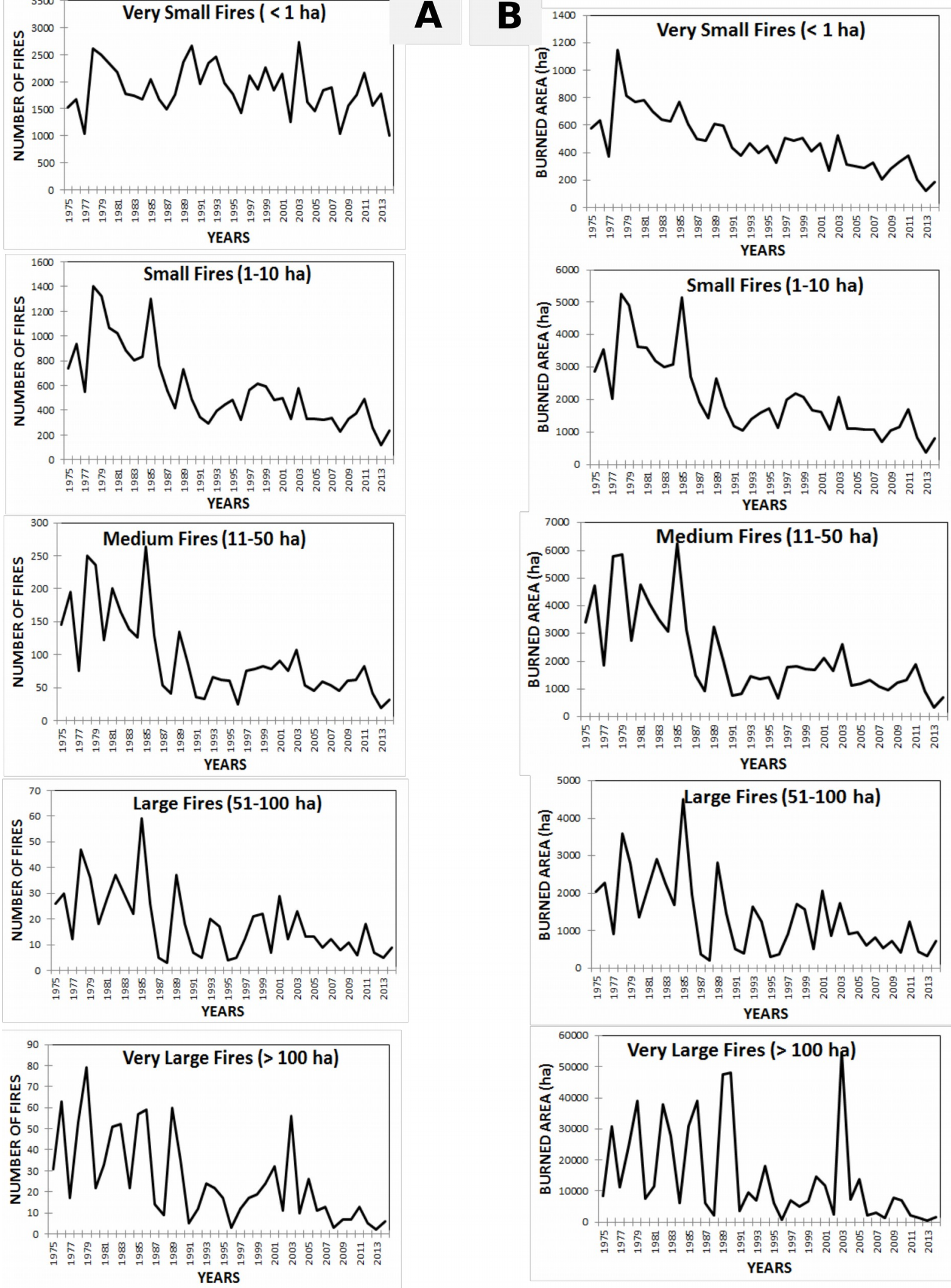
Author-produced version of the article published in Risk Analysis, 2018, 38, 3, 524-533.

The original publication is available at https://onlinelibrary.wiley.com/doi/full/10.1111/risa.12855

DOI: $10.1111 /$ risa.12855

Fig. 4
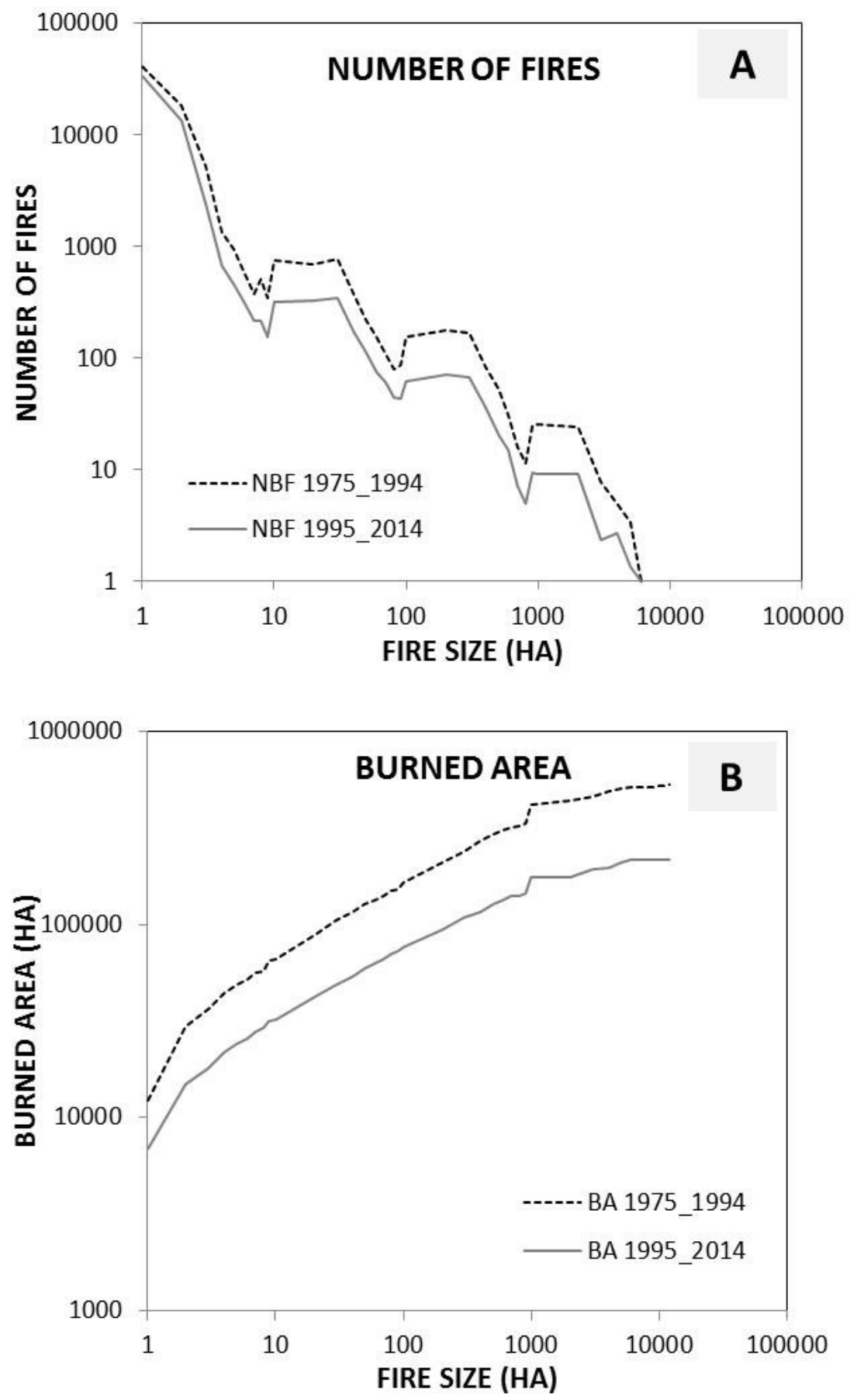
Author-produced version of the article published in Risk Analysis, 2018, 38, 3, 524-533.

The original publication is available at https://onlinelibrary.wiley.com/doi/full/10.1111/risa.12855

DOI: $10.1111 /$ risa.12855

Fig. 5
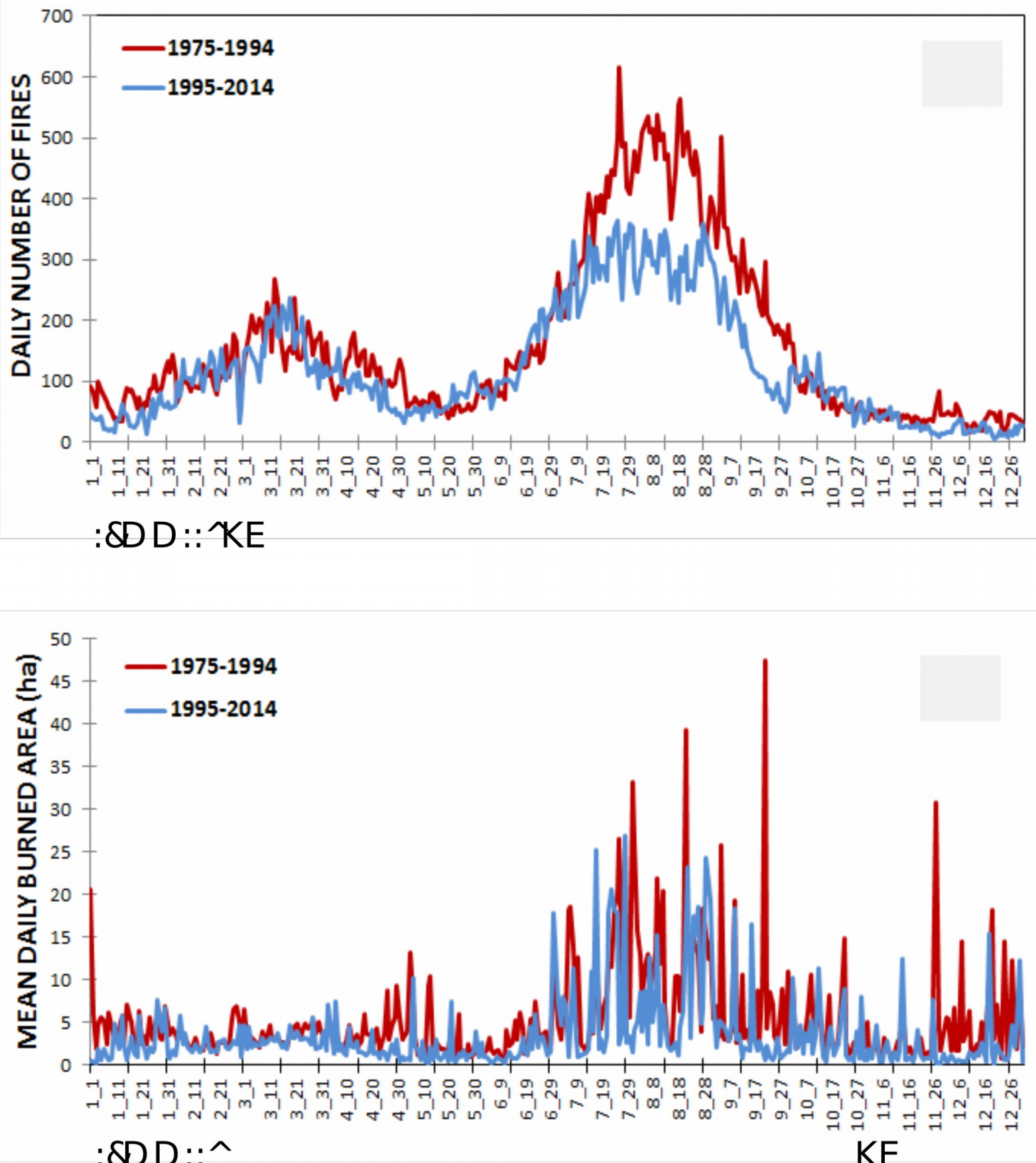
Author-produced version of the article published in Risk Analysis, 2018, 38, 3, 524-533.

The original publication is available at https://onlinelibrary.wiley.com/doi/full/10.1111/risa.12855 DOI: $10.1111 /$ risa.12855

Fig. 6

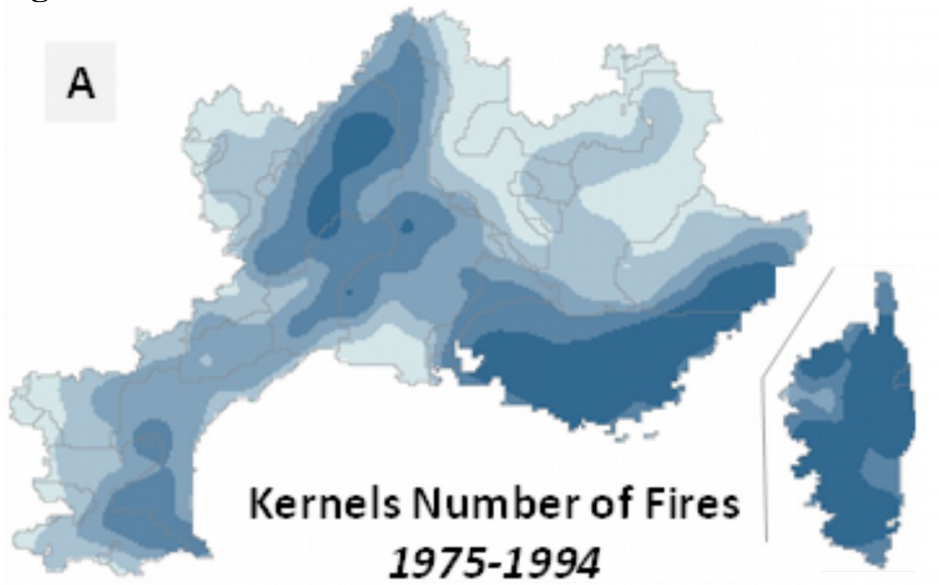
$\mathrm{n} . \mathrm{km}^{2} \cdot \mathrm{yr}^{-1}$
0
$0.01-0.05$
$0.06-0.20$
$0.21-0.80$
$>0.80$

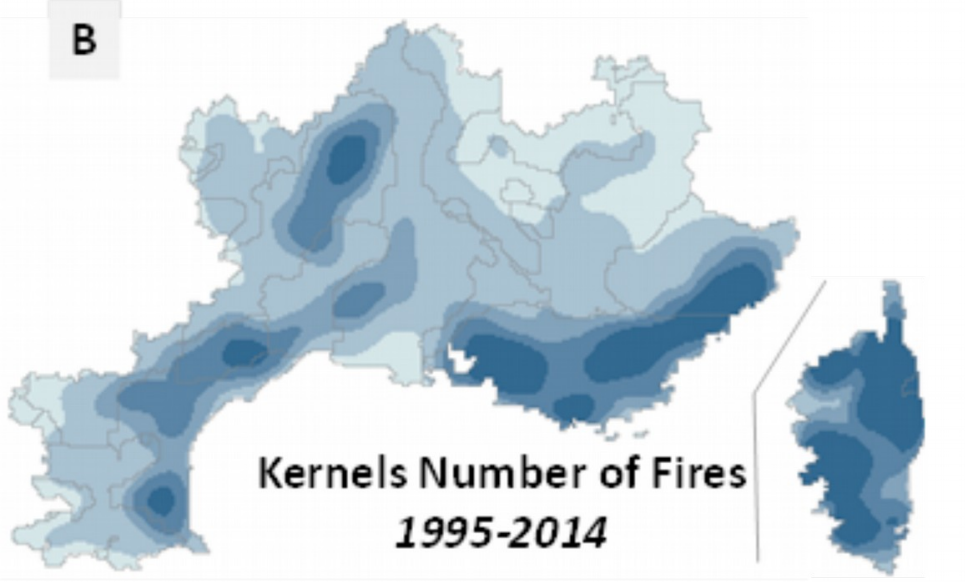

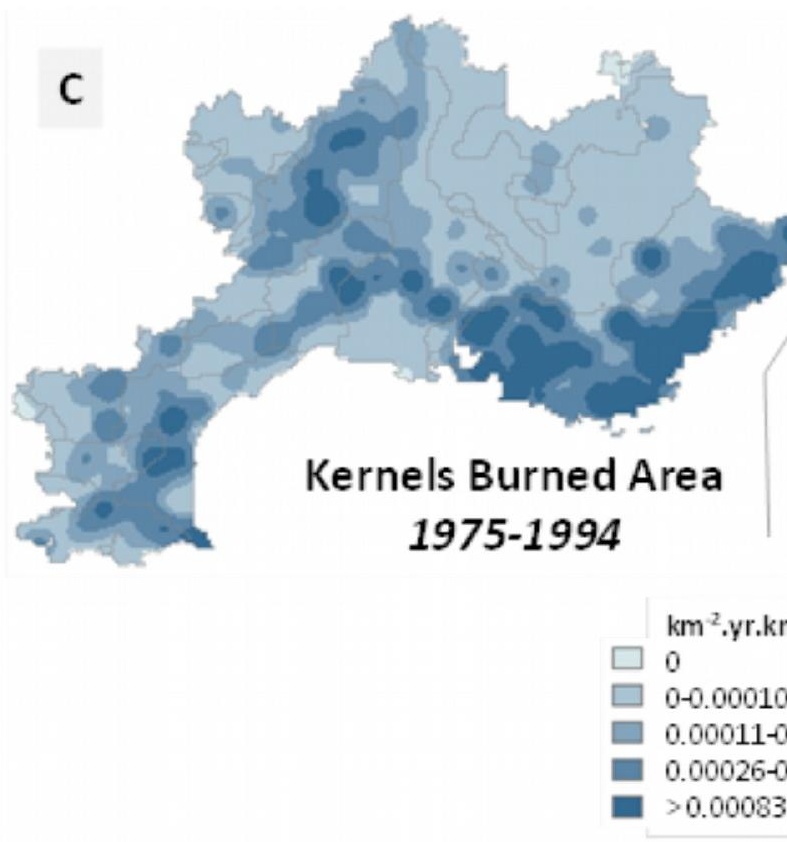

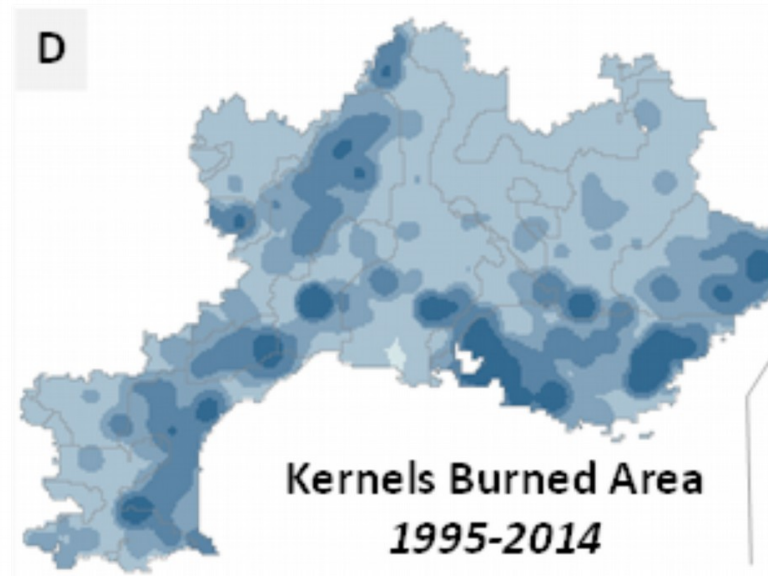


Fig. 7

Mean Annual Number of Fires

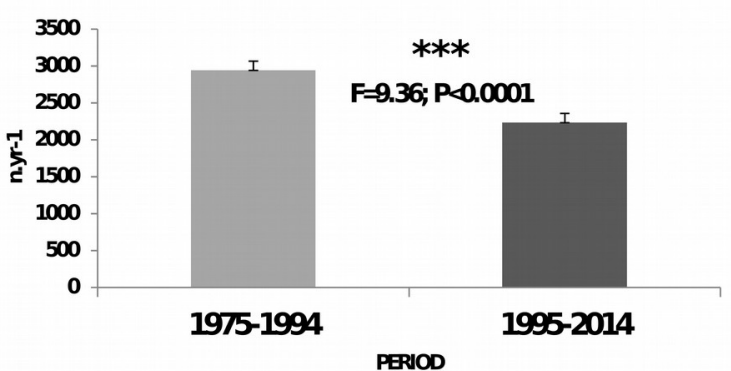

Mean Annual Bumed Area (ha)

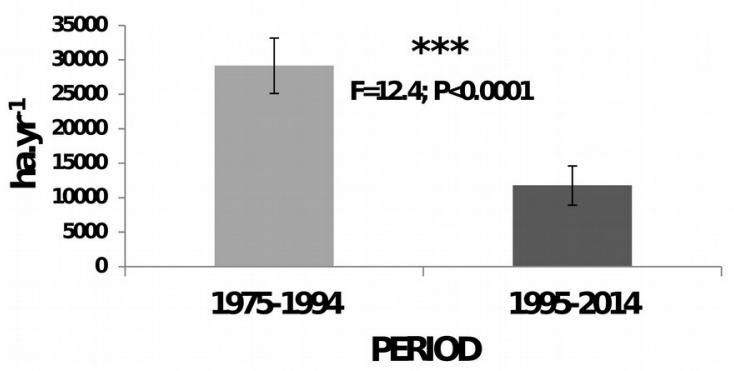

Fire Weather Index

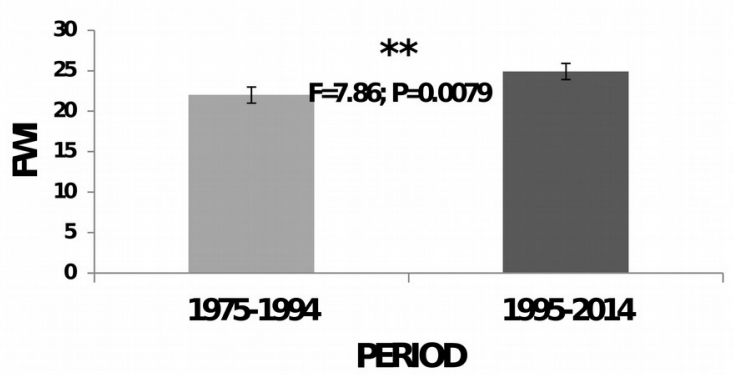

Total Full Coverage ( $\left(\mathrm{km}^{2}\right)$

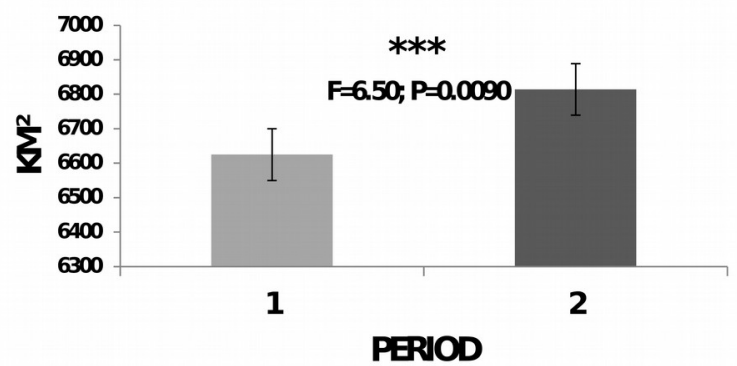

Human Pressure Index

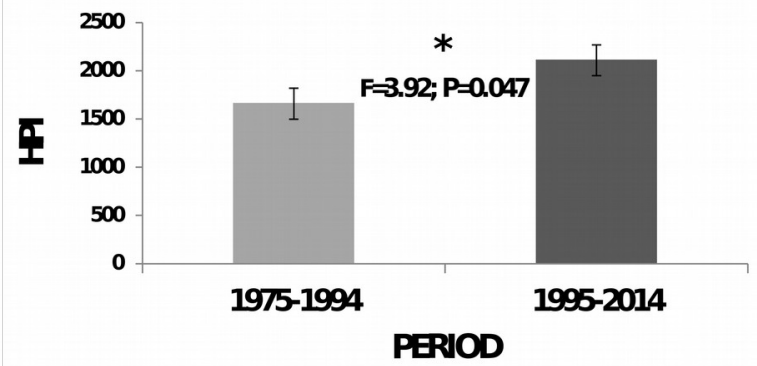


Fig. 8

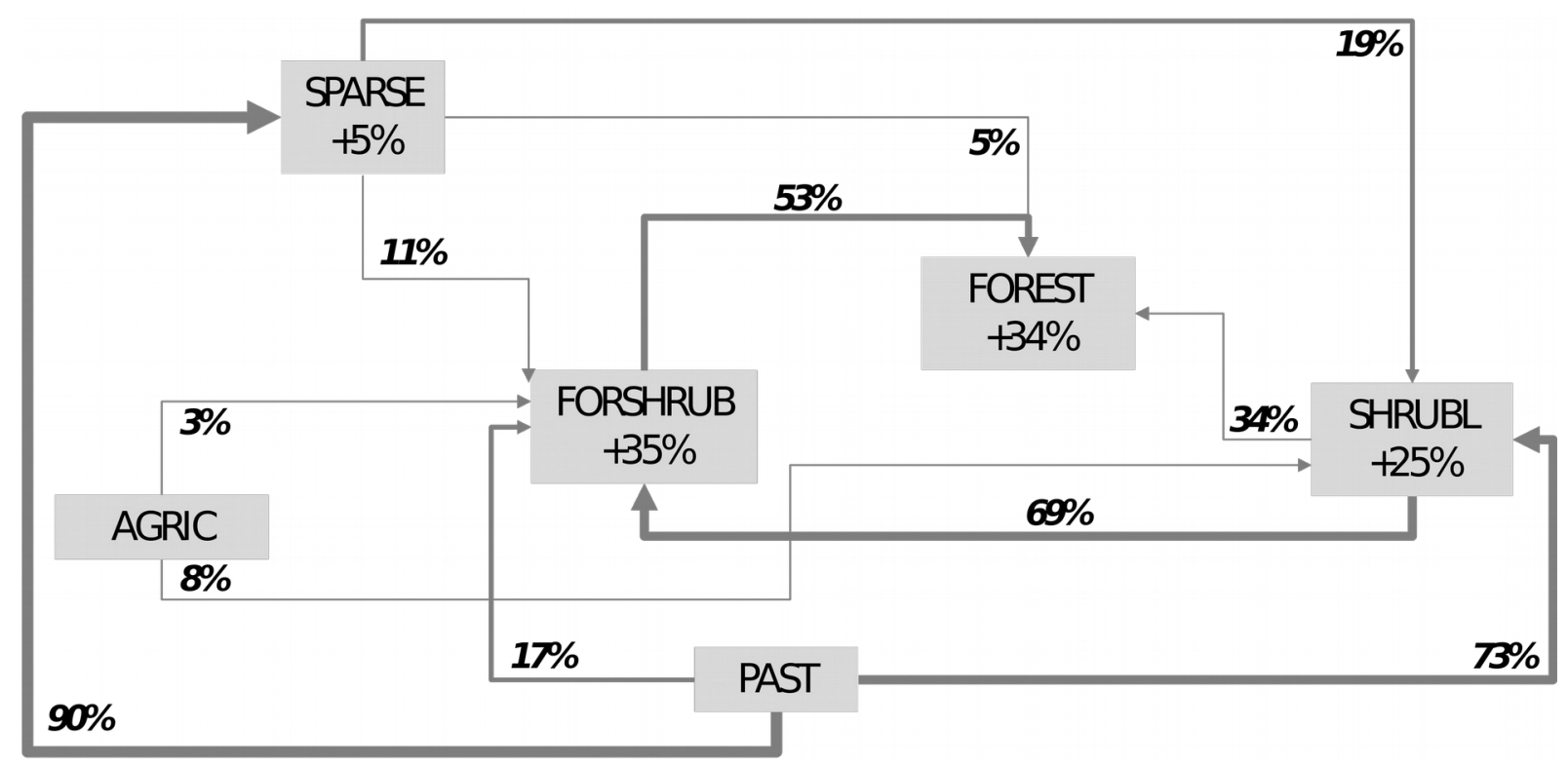


Fig. 9
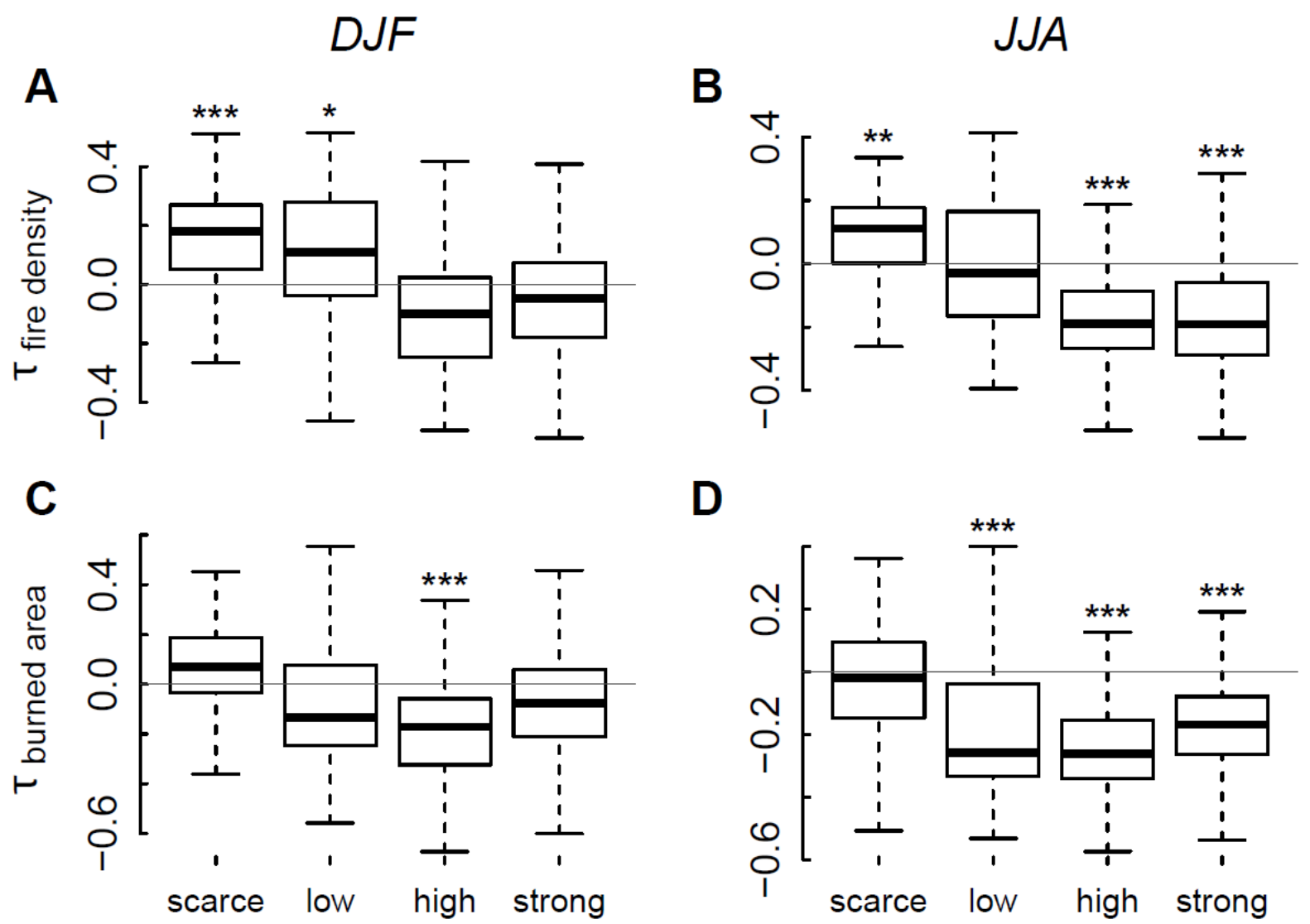

fire suppression index 
Fig. 10 


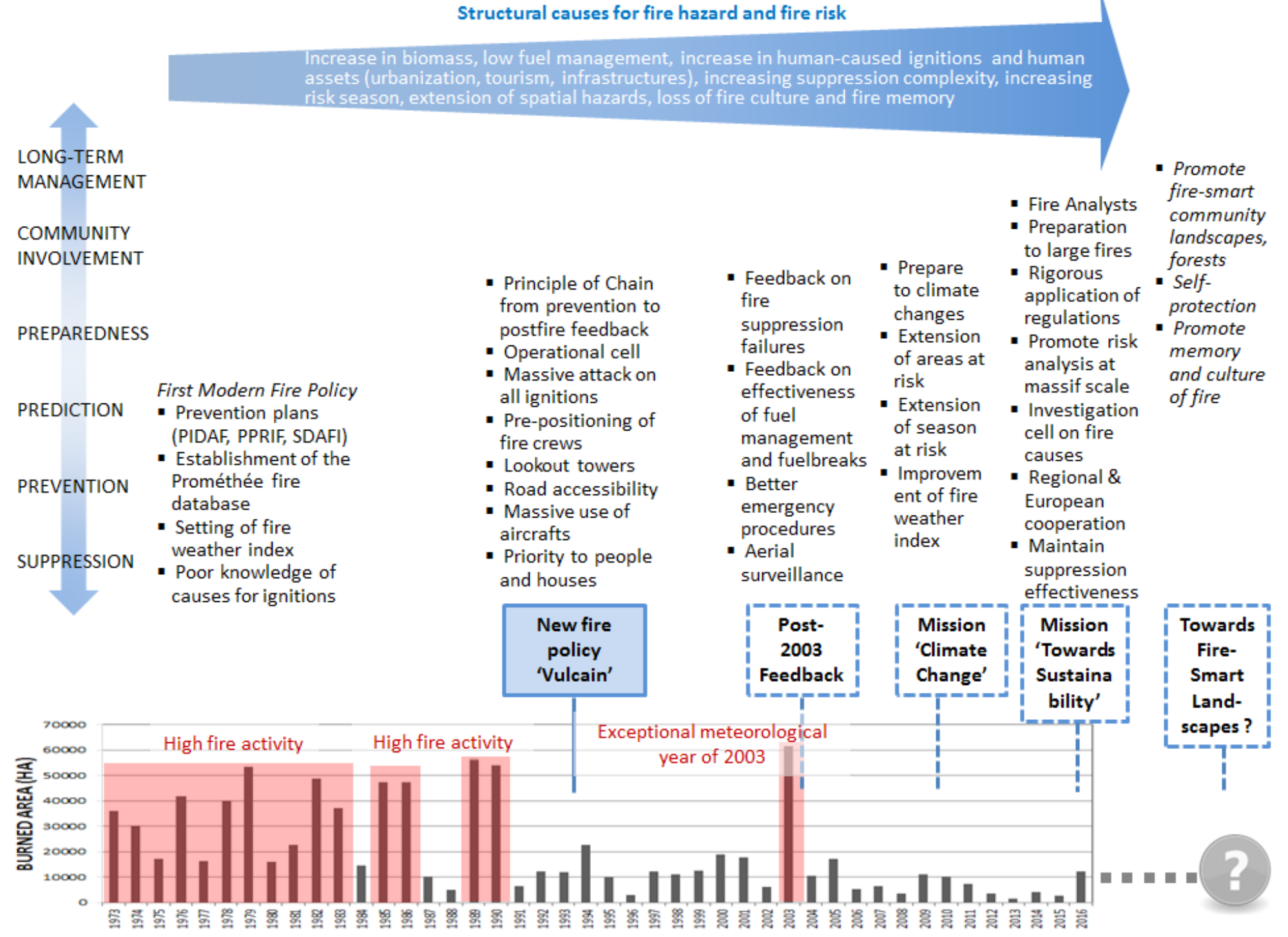




\section{REFERENCES}

1. Pausas JG, Paula S. Fuel shapes the fire-climate relationship: evidence from Mediterranean ecosystems. Global Ecology and Biogeography. 2012;21(11):1074-82. doi: 10.1111/j.1466-8238.2012.00769.x. PubMed PMID: WOS:000310252100003.

2. Pausas JG, Ribeiro E. The global fire-productivity relationship. Global Ecology and Biogeography. 2013;22(6):728-36. doi: 10.1111/geb.12043.

3. Parisien M-A, Moritz MA. Environmental controls on the distribution of wildfire at multiple spatial scales. Ecological Monographs. 2009;79(1):127-54. doi: 10.1890/07-1289.1. PubMed PMID: WOS:000263566600007.

4. Knorr W, Arneth A, Jiang L. Demographic controls of future global fire risk. Nature Clim Change. 2016;6(8):781-5. doi: 10.1038/nclimate2999

http://www.nature.com/nclimate/journal/v6/n8/abs/nclimate2999.html\#supplementary-information.

5. Pausas JG, Keeley JE. Abrupt Climate-Independent Fire Regime Changes. Ecosystems. 2014;17(6):1109-20. doi: 10.1007/s10021-014-9773-5. PubMed PMID: WOS:000340554700013.

6. Pyne SJ, Andrews PL, Laven RD. Introduction to wildland fire. 2nd ed New York, NY: John Wiley \& Sons. 1996:808 pp. PubMed PMID: CABI:19970604058.

7. Fréjaville T, Curt T. Spatiotemporal patterns of changes in fire regime and climate: defining the pyroclimates of south-eastern France (Mediterranean Basin). Climatic Change. 2015;129:239-51.

8. EFIMED F. Wildfire Prevention in the Mediterranean. A key issue to reduce the increasing risks of Mediterranean wildfires in the context of Climate Changes. A Position Paper. Second Mediterranean Forest Week, Avignon (France) April 2011. 2011.

9. Castellnou M, Larrañaga A, Miralles M, Molina D. Improving wildfire scenarios: Learning from experience. EFI Research Report 'Towards Integrated Fire Management - Outcomes of the European Project Fire Paradox', European commission 23. 2010:121-33.

10. Lahaye S, Curt T, Paradis L, Hély C. Classification of large wildfires in South-Eastern France to adapt suppression strategies. Advances in Forest Fire Research (DX Viegas Ed), Coimbra, Portugal. 2014:696-708. doi: doi.org/10.14195/978-989-26-0884-6.

11. San-Miguel-Ayanz J, Manuel Moreno J, Camia A. Analysis of large fires in European Mediterranean landscapes: Lessons learned and perspectives. Forest Ecology and Management. 2013;294:11-22. doi: 10.1016/j.foreco.2012.10.050. PubMed PMID: WOS:000317544900003.

12. DSC. Protection de la forêt contre l'incendie guide de stratégie générale Ministère de l'intérieur et de l'aménagement du territoire, Direction de la sécurité civile (A Battesti, coord). 1994:14 pp.

13. Chatry C, Le Gallou J, Le Quentrec M, Lafitte J, Laurens D, Creuchet D, et al. Rapport de la mission interministérielle "Changements climatiques et extension des zones sensibles aux feux de forêts" (National Report on Climate Change and the Extension of Fire Prone Areas in France'). Rapport Min Alimentation Agriculture Pêche $\mathrm{n}^{\circ}$ 1796. 2010:89 pp. + annexes.

14. North MP, Stephens SL, Collins BM, Agee JK, Aplet G, Franklin JF, et al. Reform forest fire management. Science. 2015;349(6254):1280-1. doi: 10.1126/science.aab2356. PubMed PMID: WOS:000361357700019.

15. Steelman TA, Burke CA. Is Wildfire Policy in the United States Sustainable? Journal of Forestry. 2007;105(2):67-72.

16. Moritz MA, Batllori E, Bradstock RA, Gill AM, Handmer J, Hessburg PF, et al. Learning to coexist with wildfire. Nature. 2014;515(7525):58-66. doi: 10.1038/nature13946. PubMed PMID: WOS:000344187500029.

17. Tedim F, Leone V, Xanthopoulos G. Wildfire risk management in Europe: the challenge of seeing the 'forest' not just the 'trees'. Proceedings 13th Intern Wildfire Safety Summit, April 2015, Boise, Idaho (USA). 2015:14 pp.

18. Cumming SG. Effective fire suppression in boreal forests. Canadian Journal of Forest Research-Revue Canadienne De Recherche Forestiere. 2005;35(4):772-86. doi: 10.1139/x04-174. PubMed PMID: WOS:000229414600002.

19. Schoennagel T, Smithwick EAH, Turner MG. Landscape heterogeneity following large fires: insights from Yellowstone National Park, USA. International Journal of Wildland Fire. 2008;17(6):742-53. PubMed PMID: WOS:000262765900006.

20. Stephens SL, Ruth LW. Federal forest-fire policy in the United States. Ecological Applications. 2005;15(2):532-42. PubMed PMID: WOS:000228059000011. 
21. Turco M, Llasat M-C, Tudela A, Castro X, Provenzale A. Decreasing fires in a Mediterranean region (1970-2010, NE Spain). Nat Hazards Earth Syst Sci. 2013;13:649-52.

22. Turco M, Bedia J, Di Liberto F, Fiorucci P, von Hardenberg J, Koutsias N, et al. Decreasing Fires in Mediterranean Europe. PLoS ONE. 2016;11(3):e0150663. doi: 10.1371/journal.pone.0150663.

23. San-Miguel-Ayanz J, Moreno JM, Camia A. Analysis of large fires in European Mediterranean landscapes: Lessons learned and perspectives. Forest Ecology and Management. 2013;294(0):11-22. doi: http://dx.doi.org/10.1016/i.foreco.2012.10.050.

24. Sande Silva J, Rego F, Fernandes P, Rigolot E, (Eds.). Towards Integrated Fire Management Outcomes of the European Project Fire Paradox. European Forest Institute Research Report 23 (European Forest Institute). 2010:228 pp.

25. Minnich RA. Fire mosaics in Southern-California and Northern Baja California. Science. 1983;219(4590):1287-94. PubMed PMID: WOS:A1983QE92200011.

26. Keeley JE, Fotheringham CJ, Morais M. Reexamining fire suppression impacts on brushland fire regimes. Science (Washington). 1999(No. 5421):1829-32. PubMed PMID: CABI:19990609859.

27. Keeley JE, Zedler PH. Large, high-intensity fire events in southern California shrublands: debunking the fine-grain age patch model. Ecological Applications. 2009;19(1):69-94. PubMed PMID: WOS:000263516200006.

28. Moritz MA. Spatiotemporal analysis of controls on shrubland fire regimes: Age dependency and fire hazard. Ecology. 2003;84(2):351-61. PubMed PMID: WOS:000181482600008.

29. Pinol J, Beven K, Viegas D. Modelling the effect of fire-exclusion and prescribed fire on wildfire size in Mediterranean ecosystems. Ecological Modelling. 2005;183(4):397-409. PubMed PMID: WOS:000228029400004.

30. Pinol J, Castellnou M, Beven KJ. Conditioning uncertainty in ecological models: Assessing the impact of fire management strategies. Ecological Modelling. 2007;207(1):34-44. PubMed PMID: WOS:000249418200005.

31. Brotons L, Aquilué N, de Cáceres M, Fortin M-J, Fall A. How Fire History, Fire Suppression Practices and Climate Change Affect Wildfire Regimes in Mediterranean Landscapes. PLoS ONE. 2013;8(5):e62392.

32. Pausas J, Fernandez-Munoz S. Fire regime changes in the Western Mediterranean Basin: from fuellimited to drought-driven fire regime. Climatic Change. 2012;110(1-2):215-26. doi: 10.1007/s10584-011-0060-6. PubMed PMID: WOS:000297910300012.

33. Salis M, Ager A, Finney M, Arca B, Spano D. Analyzing spatiotemporal changes in wildfire regime and exposure across a Mediterranean fire-prone area. Natural Hazards. 2014;71:1389-418.

34. Ruffault J, Mouillot F. How a new fire-suppression policy can abruptly reshape the fire-weather relationship. Ecosphere. 2015;6(10). doi: 10.1890/es15-00182.1. PubMed PMID: WOS:000364024300028.

35. Lloret F, Calvo, E, Pons, X, Diaz-Delgado, R. Wildfires and landscape patterns in the Eastern Iberian Peninsula. Landscape Ecology. 2002(17):745-59.

36. Moreira F, Viedma O, Arianoutsou M, Curt T, Koutsias N, Rigolot E, et al. Landscape-wildfire interactions in southern Europe: implications for landscape management. Journal of Environmental Management. 2011;92(10):2389-402.

37. Curt T, Borgniet L, Bouillon C. Wildfire frequency varies with the size and shape of fuel types in southeastern France: Implications for environmental management. Journal of Environmental Management. 2013;117:150-61.

38. Ruffault J, Moron V, Trigo RM, Curt T. Objective identification of multiple large fire climatologies: an application to a Mediterranean ecosystem. Environmental Research Letters. 2016;11(7):075006.

39. Prométhée. La banque de données sur les incendies de forêts en région Méditerranéenne en France. The French fire dabatase. http://wwwprometheecom/. 2016.

40. Pereira MG, Malamud BD, Trigo RM, Alves PI. The history and characteristics of the 1980-2005 Portuguese rural fire database. Nat Hazards Earth Syst Sci. 2011;11(12):3343-58. doi: 10.5194/nhess-11-33432011.

41. Alexandrian D, Esnault F. Public policies affecting forest fires in the Mediterranean Basin. In FAO Meeting on public policies affecting forest fires, Rome (Italy), 28-30 October 1998, pp 45-63. 1999;FAO Forestry Paper 138, Rome (Italy). ISBN 92-5-204289-X, ISSN 1014-2894.

42. Perriez F, Bartet J, Barthélémy F, Foin P, Battesti J, David J. Rapport sur la protection contre les incendies de forêt après les feux de l'été 2003 (Report on the protection against forest fires afeter the 2003 summer wildfires). IGA, CGGREF, IGE, CGPC Report. 2003:84 pp. + appendices.

43. R Development Core Team. R: A language and environment for statistical computing, reference index version v. 2.14.1. R Foundation for Statistical Computing, Vienna, Austria. 2011(http://WWW.Rproject.org.). 
44. Koutsias N, Kalabokidis K, AllgöWer B. Fire occurrence patterns at landscape level: beyond positional accuracy of ignition points with kernel density estimation methods. Natural Resource Modeling. 2004;17(4):35975.

45. de la Riva J, Perez-Cabello F, Lana-Renault N, Koutsias N. Mapping wildfire occurrence at regional scale. Remote Sensing of Environment. 2004;92(2):288-94. doi: 10.1016/j.rse.2004.06.013. PubMed PMID: WOS:000223568200013.

46. Gonzalez-Olabarria JR, Mola-Yudego B, Pukkala T, Palahi M. Using multiscale spatial analysis to assess fire ignition density in Catalonia, Spain. Annals of Forest Science. 2011;68(4):861-71. doi: 10.1007/s13595-011-0082-2. PubMed PMID: WOS:000292553400019.

47. Parisien MA, Moritz MA. Environmental controls on the distribution of wildfire at multiple spatial scales. Ecological Monographs. 2009;79(1):127-54. doi: 10.1890/07-1289.1. PubMed PMID: WOS:000263566600007.

48. van Wagner C. Development and structure of the Canadian Forest Fire Weather Index System. Forestry Technical Report - Canadian Forestry Service. 1987(No. 35):viii + 37 pp. PubMed PMID: CABI:19910646918.

49. Vidal J, Martin E, Franchistéguy L, Baillon M, Soubeyroux J. A 50-year high-resolution atmospheric reanalysis over France with the Safran system. International Journal of Climatology. 2010;30(11):1627-44.

50. Zimmermann N, Gebetsroither E, Züger J, Schmatz D, Psomas A. Future Climate of the European Alps. In: Cerbu GA (Ed), Chapter 6 - Management Strategies to Adapt Alpine Space Forests to Climate Change Risks, InTech Publ. 2013:28 pp.

51. Ruffault J, Moron V, Trigo R, Curt T. Daily synoptic conditions associated with large fire occurrence in Mediterranean France: evidence for a wind-driven fire regime. Int J Climatology. 2016:1-10.

52. Curt T, Fréjaville T, Lahaye S. Modelling the spatial patterns of ignition causes and fire regime features in southern France: implications for fire prevention policy. International Journal of Wildland Fire. 2016;25(7):785-96. doi: http://dx.doi.org/10.1071/WF15205.

53. Feranec J, Soukup T. Map presentation of changes in Europe's artificial surfaces for the periods 19902000 and 2000-2006. Central European Journal of Geosciences. 2013;5(2):323-30. doi: 10.2478/s13533-0120132-9. PubMed PMID: WOS:000321111600010.

54. Lampin-Maillet C, Long-Fournel M, Ganteaume A, Jappiot M, Ferrier JP. Land cover analysis in wildland-urban interfaces according to wildfire risk: A case study in the South of France. Forest Ecology and Management. 2011;261(12):2200-13. doi: 10.1016/j.foreco.2010.11.022. PubMed PMID: WOS:000291504500004.

55. Ruffault J, Moron V, Trigo RM, Curt T. Daily synoptic conditions associated with large fire occurrence in Mediterranean France: evidence for a wind-driven fire regime. International Journal of Climatology. 2017;37(1):524-33. doi: 10.1002/joc.4680. PubMed PMID: WOS:000392415700039.

56. Schmuck G, San-Miguel-Ayanz J, Camia A, Durrant T, Boca R, Libertà G, et al. Forest Fires in Europe, Middle East and North Africa in 2013. Joint Research Center report and EC DG Environment. 2014:107 pp. doi: doi: $10.2788 / 99870$.

57. Rodrigues M, San Miguel J, Oliveira S, Moreira F, Camia A. An Insight into Spatial-Temporal Trends of Fire Ignitions and Burned Areas in the European Mediterranean Countries. Journal of Earth Science and Engineering. 2013(3):497-505.

58. Vélez Muñoz R. Europe: Development and Fire. In 'Proceedings of the second international symposium on fire economics, planning, and policy: a global view' Gen Tech Rep PSW-GTR-208, (Dept Agric Forest Service, Pacific Southwest Research Station (Albany, CA, US). 2008:213-9

59. Makala A, Gohier del Ré A, Dereix C, Brandeis A, Grandjean M, Granger Y. Mission d'évaluation relative à la défense de la forêt contre l'incendie (Mission of protection of forests against fire). CGEDD, IGA, CGAAER (Paris, France) April, 2016. 2016:145 pp. + appendices.

60. McIntosh R, Tainter J, McIntosh S. The Way the Wind Blows: Climate, History and Human Action. Columbia University Press, New York, New York, USA. 2000:200 pp.

61. Lindner M, Maroschek M, Netherer S, Kremer A, Barbati A, Garcia-Gonzalo J, et al. Climate change impacts, adaptive capacity, and vulnerability of European forest ecosystems. Forest Ecology and Management. 2010;259(4):698-709.

62. Doblas-Miranda E, Martínez-Vilalta J, Lloret F, Álvarez A, Ávila A, Bonet FJ, et al. Reassessing global change research priorities in mediterranean terrestrial ecosystems: how far have we come and where do we go from here? Global Ecology and Biogeography. 2015;24(1):25-43. doi: 10.1111/geb.12224.

63. Moriondo M, Good P, Durao R, Bindi M, Giannakopoulos C, Corte-Real J. Potential impact of climate change on fire risk in the Mediterranean area. Climate Research. 2006;31(1):85-95. PubMed PMID: WOS:000240057000008. 
64. Giannakopoulos C, LeSager P, Moriondo M, Bindi M, Karali A, Hatzaki M, et al. Comparison of fire danger indices in the Mediterranean for present day conditions. Iforest-Biogeosciences and Forestry. 2012;5:197203. doi: 10.3832/ifor0622-005. PubMed PMID: WOS:000308064900003.

65. Collins RD, de Neufville R, Claro J, Oliveira T, Pacheco AP. Forest fire management to avoid unintended consequences: A case study of Portugal using system dynamics. Journal of Environmental Management. 2013;130:1-9. doi: 10.1016/j.jenvman.2013.08.033. PubMed PMID: WOS:000328869600001.

66. FUME. FUME Project: Forest fires under climate, social and economic changes in Europe, the Mediterranean and other fire-affected areas of the world. Lessons learned and outlook. European Community 7 th Framework Programme, José M Moreno (Ed). 2014:32 pp.

67. Castellnou M, Miralles M. The great fire changes in the Mediterranean - the example of Catalonia, Spain. Crisis Response 2009;5(4):56-7.

68. Valese E, Conedera M, Held A, Ascoli D. Fire, humans and landscape in the European Alpine Region during the Holocene. Anthropocene. 2014;6:63-74.

69. Tedim F, Remelgado R, Martins J, Carvalho S. The largest forest fires in Portugal: the constraints of burned area size on the comprehension of fire severity. Journal of Environmental Biology. 2015;36(1):133-43. PubMed PMID: WOS:000348489500019.

70. Tedim F, Leone V, Xanthopoulos G. A wildfire risk management concept based on a social-ecological approach in the European Union: Fire Smart Territory. International Journal of Disaster Risk Reduction. 2016;18:138-53. doi: 10.1016/j.ijdrr.2016.06.005. PubMed PMID: WOS:000384837500015. 